\title{
Significance and Impact of Ancient Rome and Its Relevance in the Current Global Order
}

\author{
Vishnu Prabhu K.S \\ Research Associate, School of Social Sciences and Languages, VIT University, Vellore, India \\ Email: ksvishnuprabhu@icloud.com \\ Dr. Laxmi Dhar Dwivedi
}

Associate Professor, School of Social Sciences and Languages, VIT University, Vellore, India Email: laxmidhar@vit.ac.in

\section{Doi:10.5901/mjss.2015.v6n5s2p51}

\begin{abstract}
Michel Foucault one of the most influential authorities on power politics contemplates that power has the character of a network and that its threads extend everywhere. The Ancient Rome was one of the most advanced civilizations armed with military and diplomatic muscle combined with rich cultural and engineering marvels. Rome became the supreme Mediterranean power around 242 BC with the defeat of the Carthage in the First Punic War (264 - 241 BC). The role of Italy in The European Union (EU), NATO and the World at large has had its similar roots manifested through alliances thousands of years ago. Developed nations like Italy are defined by both its Hard and Soft powers. The dire need to study this power projection stem from the various aspects that defined ancient Rome as one of the most developed civilizations. Her tentacles of power need to be analyzed and be compared with respect to the modern day governance. The paper also traces the origin and history of the projection of ancient Roman power both on hard and soft connotations and attempts to parley on its significance and relevance in today's global world order. The methodology pursued in the paper involves unraveling the special features and characteristics of ancient Rome and the modern day Italy from Military, Trade, Economy and Architectural stand point and attempts to strike a chord between its similarities and differences.
\end{abstract}

Keywords: Ancient, Rome, Global, Power, History, Order.

\section{Introduction}

The recent $40^{\text {th }}$ anniversary of the Armani as one of the world's foremost pioneering fashion brands and the much talked about movie on Enzo Ferrari's biopic have one thing in common; they continue to project Italy's soft power which draws the world's attention calling to its doors. It has not just become a luxury to own these brands today but it garners pride in owning one as well.

The evolution of Rome through the early, middle and later ages has both ups and downs with respect to its civilizational growth and development. The story behind the founding of Rome to the fall of its might empire is filled with courage, commitment and dedication but is equally watered down with corruption, betrayal and injustice. William Shakespeare's Antony and Cleopatra speaks of the love that transcended between two civilizations of Rome and Egypt respectively.

The planets belonging to our solar system are also named after Roman Gods and Goddesses. It was believed that the ancient romans were to have been able to witness planets without having the telescopic technology. Such was their power with respect to astronomy. To name a few Mercury is the Winged Messenger of God, Venus is the Goddess of Love, Mars is the God of War and Jupiter is the God of Gods.

The engineering marvels of the Roman civilization are remarkable. They were one the first civilizations in the world to construct water bunds for best agricultural practices. The Roman army was one of the most advanced forces and was the toughest force to reckon with at their time. The Roman army was divided into legions numbering to about seven fifty to thousand each just like the modern day army, which has been divided into battalions.

The Romans were spiritually powerful. The kings, Emperors and the Senators offered prayers to the Gods before embarking upon major decisions. Animal sacrifice was also amply evident. Trade was key to Roman's economy. Gold had its monumental value and Rome was able to develop her empire with the use of all these attributes which it one of the most advanced civilizations in the world. 


\section{Methodology}

The methodology involved is to trace the origins of Ancient Rome, compare its evolution with the modern day Italian context and report striking similarities and differences. First, the founding of Rome and its evolution as a County, City and Civilization deems utmost importance. In the second leg, the spread of Roman influence (sphere of influence - both hard and soft power) is given ripe attention.

The Roman military strength and its architectural marvel lance are compared with the modern day Italian context. Literature, History, Trade and Economy are given specific preference in the aforesaid context. Thirdly, charismatic personalities who made significant contribution are taken into consideration. And finally, with due diligence all effort is made to record key findings in light of the inextricable relationship between ancient Rome and the modern day Italy's significance and relevance in the current global order.

\section{The Founding of Rome}

Rome according to some Historians became to be known as an Empire around $4^{\text {th }}$ century $\mathrm{BC}$ when there was a crisis in Italy when the Greeks and the Etruscans were outrun from the southwestern part of Italy. She grew up on the riverbanks of Tiber, traditionally scattered around in villages on low-lying hills, which is recalled as the Seven Hills of Rome.

The Etruscans were desolated and Rome had found its place. The city of Veii, belonging to the Etruscans was captured by Rome. Poet Propertius $\left(1^{\text {st }} \mathrm{BC}\right)$ wrote about thus:

"Veii, thou hadst a royal crown of old,

And in thy forum stood a throne of gold!

Thy walls now echo but the shepherd's horn,

And o'er thine ashes waves the summer corn.

- Freeman, Charles (1999) (pp 301: 5-8) (Translated by George Dennis)

Citizenships that we talk about today also had its roots in the early days of Rome's founding. The word 'gens' in Latin means clan. And today words like 'Netizen' in the context of digital world also have taken shape. Alba Longa was the first place to be recognized as a modern city in the $8^{\text {th }}$ century at that time with a group of colonies, which were spread at a place called Latium between the River Tiber and the Alban Hills.

The uniqueness of Latin culture gained prominence, as there were common festivals to celebrate its founding. The Romans were known to be belonging to a war society and traditionally men were buried along with their swords, which symbolized their ultimate cause for leading exemplary lives. The early Romans were also traders and became absolutely influential at their expertise cutting across boundaries to have established it successfully.

Livy (59 BC- 17 AD) the Roman historian has recorded his few glimpses on the establishment of Rome. In the following extract from his writing, which has been translated, refers to the settlement of the early Romans in the Latium region.

"Not without reason did gods and men choose this spot for the site of our city -the salubrious hills, the river to bring us produce from the inland regions, and seaborne commerce from abroad, the sea itself, near enough for convenience yet not so near as to bring danger from foreign fleets, our situation in the very heart of ltaly - all these advantages make it of all places in the world the best for a city destined to grow great."

Freeman, Charles. (1999) (pp 299: 1-6) (Livy, History of Rome, Book V) Translation: Tim Cornell.)

With the founding of Roman Empire it had also established concrete principles and laws from trade relations to diplomatic principles and from settling disputes to waging wars. Rome was republic in its founding and was the first among many other countries around the world to establish legal terminologies.

She also had created a legal terminology ius gentium, which refers to the modern terminology of law of nations that is construed by the United Nations and other international institutions like the IMF and the World Bank.

Rome realized the importance of international relations long before 'Treaty of Westphalia' came into being in 1648. She had to obtain legal permission from its Senate and also oblige the spiritual conventions of the State explaining its 'right' intent before waging a war with another.

She had diplomatic envoys sent across the world for engaging global order and also domestically settled disputes without having to create conflicts. Rome has had a tremendous success with respect to inventions and innovations in trade, weaponry, architecture and diplomatic relations. 
With the founding of Roman Empire, a rise in a new trend of global relations came into existence. Thus, making her one of the first advanced civilizations in the world armed with both Soft and Hard Power.

\section{Ancient Rome: A Mediterranean Power}

The system of Provincial Administration came into order with the respect to Rome's art of governance. In today's global order it is essentially being referred to as 'Co operative Federalism', which technically refers to the cooperation between the nation and its states. By 227 BC Rome had Governors in Sicily, Sardinia and Corsica to administer its territories. And the law of the land was given absolute prominence to deal with her everyday affairs.

The Second Punic War (218-202 BC) was a raging conflict, which brought about the first enemy of Rome to be reckoned with. 'Hannibal' the ferocious leader of the Carthaginians decided to conquer Rome. Trouble began when Hannibal attacked the town of Saguntum in 219 BC, which was an ally of Rome at the time. Hannibal mistook Rome's patience for weakness under the false pretense that Rome would not mind Saguntum's occupation by the Carthaginian army.

Rome protested at first but soon realized that the advance of Carthaginian army could very well knock on the doors of her empire as well. Having sensed the gravity of the situation that demanded immediate attention, Rome had to execute a plan in place to deal with the animosity that was to arrive. The Roman army at the time was divided into Legions, which is referred to as battalions in the modern military context.

Each Legion comprised of approximately thousand soldiers. They were armed with swords, shields and daggers. The pitched battles were necessarily open battles. But during the Second Punic War (218-202 BC) the terrain chosen by Hannibal was the cold-biting Alps Mountain.

Rome had a powerful army containing archers, siege equipment and door ramming devices, which at the time were advanced with respect to military technology. Its naval technology was one of the most advanced as well. But none of them could be used in the Alps terrain as it was one of the highest peaks in the world and the weather was not conducive unlike traditional form of open battles in the plains.

The Siachen Glacier in India happens to hold the highest military base camps in the world today. And with the advent in modern technology it is able to sustain to an extent. With the snow melting and the glacier falling; it is still a challenge to sustain with for the army.

Rome's Counsel Publius Cornelius Scipio led the Roman army in the Second Punic War (218-202 BC). He marched on Spain and began to realize that Hannibal chose to march on Rome through the Alps instead of facing the army midway.

Scipio ordered the army to march on Spain and he redirected himself towards the Alps to face Hannibal with the help of a few legions. The aforesaid tactic was bold and projects his presence of mind. The objectives set by Scipio is one of the master moves with respect to obtaining twin military objectives. One objective was to face the advancing army and other was directed toward conquering Spain.

To witness this effect in the recent times, we should turn our attention to the events that occurred during the Cold War (1945-1991), which divided the World into two powerful blocks the US in the West and the erstwhile Soviet Union in the East.

The Secret Intelligence Service (MI6) of the British between the end of The Second World War (1945) and the beginning of the Cold War created a strategy called "Operation Double Cross". The objective of the British was to capture its enemy spies and turn them to work for the British government in turn. This operation produced great results for the British War Office and the Spy office at the time.

The Roman army during the Second Punic War faced major catastrophe. It had lost about ten to twelve legions. But the allied cities of Rome like Latium, Umbria and Etruria held its ground. Roman government needed an immediate sitting to assess the situation dealing with the invading forces led by Hannibal.

Rome gave birth to Quintus Fabius Maximus, one of the greatest military tacticians in the world. The tactics unleashed by him is famously referred to as the 'Fabian Tactics'. Fabian was of the view not to send its army to the open battles but to orchestrate plans to lure in Hannibal's army into traps and thereby defeat them. But his plans failed to capture any headway due to less support received by his colleagues and the senate.

The final battle that would decide the fate of the Second Punic War (218-202 BC) was to be found in the Battle of Zama (202 BC). Scipio's military might accompanied by smart decisions and assisted by the powerful Roman cavalry defeated Hannibal and his forces. Hannibal retreated and tried to attack Rome again but with the resistance he faced with the might of the Roman Empire, he chose not to meddle with the affairs of Rome.

Scipio was gained the 'Imperator' status for his victory and thanked Neptune the God of the Sea to whom he had 
worshipped which was considered holier than thou at the time. Each ruler had worshipped his own Gods and Goddesses. The famous Julius Ceaser was also referred to as the Son of Venus.

The current global order in the $21^{\text {st }}$ century is filled with instances of US spreading its sphere of influence over the west, Russia's annexation of Crimea and China's claim on South China Sea. All these instances also had similar roots in the ancient Roman Empire with respect to spreading her sphere of influence as well.

In 205 BC Greece looked up to Rome for help when Macedonia was to invade her. Rome sent a fleet of ships towards Greek's rescue. To not only the allies of Rome, she was a big brother in terms of taking care of them, but she was also helping smaller towns and cities by bringing them under her powerful protective umbrella.

Although much of the early foundations of the Roman Empire had Greek influences from its art to aesthetics, Rome was able to welcome it and adapt it into their culture. It began what could be termed as 'Cultural Evolution'. And also Rome welcomed Greek immigrants.

Roman history and literature could also be found in the epics of Greek Poet Quintus Ennius' (239-169 BC) work Annale. Now that the Roman Empire began to realize the growing interest by its citizen towards arts and culture Gnaues Pompey Magnus, a great statesman who later became the Counsel of Rome built a stone theatre for city's plays and operas to be performed.

\section{Gaius Julius Ceaser (100 - $44 \mathrm{BC})$ : A Towering Personality}

The Hollywood movie Ides of March and William Shakespeare's Julius Ceaser have a commonality in its own merit. Both speak of the horrors that were to arrive at the end not just as a tragedy but as a catastrophe as well. And this effect could be best explained when Marcus Junius Brutus famously remarked while stabbing Ceaser: It is not that I loved you less; but I loved Rome more.

And yet again, the history of ancient Rome is definitely celebrated with courage, dedication and honor but is also equally watered down with betrayal, treachery and injustice. Ceaser as a military general and as the Roman Counsel achieved what no other could during his times and ever more. The defeat of Gauls in Africa brought Ceaser to the forefront of Rome, which was by ravaged civil wars at the time.

Home Box Office's (HBO) TV series 'Rome' again reminded the world in the recent past of the prominence attributed to ancient Rome. The series is based on the lives around Lucius Vorenus and Titus Pullo who belonged to the $11^{\text {th }}$ Roman Legion of Ceaser. In the writings of Ceaser it is believed that these centurions (who were invincible in battles) found their places. They were also considered loyalists to their ruler.

With Ceaser's Counsel ship along with his friend and military general Mark Antony, Rome far from being a Mediterranean power also reached the shores of Egypt. The Roman Empire extended from Spain in the West to Egypt in Far East.

One of the best qualities of Ceaser among many was his magnanimity towards his enemies. Julius Ceaser offered pardoned his enemies and exemplified mercy, which was very rare among Roman military commanders at the time. In $63 \mathrm{BC}$, the young Ceaser was appointed Pontifex Maximus a post dignified for life. In today's parlence, it could be referred and compared to Titles being conferred such as 'Knighthood' and 'Lordship' by the United Kingdom.

Great Orators like Marcus Tulius Cicero, Martin Luther King, Mahatma Gandhi and Barrack Obama have all possess a striking similarity. It is not only because of their oratory skills that they became overtly popular but also because of their charisma that they carried with them. And Ceaser was by far no exception to it. He was a great orator and an expert military strategist. It is being considered a rare trait among many leaders at the time.

In about 59 BC Rome's governance position was unstable. There was immense power struggle between Ceaser, Pompey and Crassus as to who will be ruling Rome. Ceaser had already secured the governorship of Gaul and Illyricum. The power struggle between them could not survive for long. Ceaser did manage to consolidate his position as the Counsel of Rome.

Pompey and Crassus did manage to get their own respective positions with Ceaser enabling them by attending to their welfare and to a great deal Ceaser arranged for the welfare of the veterans who fought with the legions alongside Pompey and Crassus as well. This was Ceaser's master move and also enabled Rome to return to peace, which was broken into pieces due to the civil wars that ravaged it.

Julius Ceaser strived to create an international order. By the time he secured the Imperator position as the Chief Consul of Rome, Cicero had also convinced the Senate to adhere to that effect. Ceaser had great regards for Marcus Tulius Cicero, who was at the time one of the best orators. Through his help, Ceaser was appointed as the Imperator for about ten years in $46 \mathrm{BC}$. And by $44 \mathrm{BC}$ he was made Consul for life. 
Ceaser took great strides in settling the political situation in Rome by taking on the reins. Also rampant corruption practices were crumbling Rome's economy. By now Rome had its regions spread over from Spain to Egypt and all the way to Asia. Ceaser greatly entrusted his affairs to Mark Antony who was his second in command.

Under the able leadership of Ceaser, taxes were collected from the citizens directly by the state and not through collectors. And rigorous steps were also taken to stop bribery practices throughout Rome, which was quintessentially important to Ceaser's rule towards creating a fruitful and developing society.

Growing dissent in the Roman Senate began to ponder over Ceaser's rule. They wanted Rome to return to the rule of Republic and thereby dissuading her from the clutches of Monarchy. Cassius and Brutus were the chief conspirators and orchestrated a plan to assassinate Ceaser. On March $15^{\text {th }}, 44$ BC his friend Brutus stabbed Ceaser and thereby bringing about his ultimate downfall.

\section{Roman Military and Architecture}

In the current world order 'Super Power' is the status given to countries to designate its influence and dominance over others. The US, UK, France, Russia and China are considered to be competing among themselves to be the 'super power' of the $21^{\text {st }}$ century although the US is currently playing that role.

Ancient Rome was a 'super power'. Its technology and know how brought world's attention to its doors. The Romans had advanced armies and navies. The army was divided into legions and navy into fleets.

Unlike State control on the Army, the legions could also recruit by themselves which was fairly a welcome change even in that time. To best explain its practice, Flavius Vegetius Renatus in the Fourth and Fifth century wrote thus:

\section{"The Roman people owed the conquest of the world to no other cause the military training, discipline in their camps, and practice in the warfare"}

Freeman, Charles (1999) (pp 436: 21-22)

\section{(Translation: N. Lewis and M. Reinhold)}

The army legions' power and sustenance solely did not rely on its military might alone but also rested with the social mobility to which it garnered great reverence. Order of merit was given preference and local men could enlist themselves raniging from a baker to ironsmith.

The special forces of Italy 'Col Moschin' (9'h Parachute Assault Regiment) were primarily created for carrying out special tasks. And likewise the ancient roman army had special cavalry for carrying out special tasks upon requirement.

The city of Naples in Italy today receives about hundreds of thousands of tourists and travelers every year. The long beaches and vast coastline adds up to the overall scenic beauty of Italy. The coastline served as a model cultural hub, which was even more advanced than the city of Latium at the time.

Dan Brown's novel Angels and Demons (2000) projects some of the greatest architecture marvels in Rome today like St. Peters Square, The Sistine Chapel and The Castle of the Angel which were all products of Renaissance. But Rome had its architectural roots hundreds of centuries ago, which scholars believe that the renaissance architects gained inspiration from the Roman texts.

The initial buildings of prominence were built using bricks and stones. Pompey did commission a stone theatre, which was built in $55 \mathrm{BC}$. And during the time of Emperor Augustus marble stones were used for the first time to build The Senate, Amphitheaters and Markets.

The Roman engineers had to device new and cordial methods to bring water to the city because most of Rome was dependent on River Tiber for the consumption of water. And they ensured that water reached its citizens through construction of water bunks and also which in turn helped agriculture. This not only helped the city dwellers to receive water but also enabled the poor to receive their fair share of treatment.

Vitruvius' treatise De Architectura contains whole lot of designs and plans for constructing amphitheaters, basilicas and temples. According to historians and scholars this text of Vitruvian's served as an inspiration for many Renaissance architects. Emperor Nero commissioned 'Domus Augustana' which a huge building that was considered one of the finest architectural marvels at the time.

If it was the Roman military might that projected its hard power then in sharp similarity it was its marvelous architecture that shaped its soft power. Italian Navy's Aircraft carrier Cavour was named after Camillo Benso Conti Di Cavour who was one of the finest Italian statesmen and politicians. And the Leaning Tower of Pisa built by Bonanno Pisano stand testimony to that effect. 


\section{Roman Economy and Trade}

Currency value of any country is determined by its gold reserves. And the current global order also trades on the import and export of Oil and the trade balance and imbalance is vehemently determined by it. Fort Knox in the US contains the gold reserves and likewise every other country stocks its own.

Rome was not necessarily rich. But it was wealthy. The difference in them falls under two narratives. One narrative stipulates that Rome gathered enough gold reserves in order to sustain. And the other narrative is that it also enabled its citizens to gain wealth by paying taxes into the system. In other words, monetary ailments were successfully revolving around at the time for a brief period. And Italy is one of the top ten performing economies today in the world.

Venice is a tourist hub today and likewise Sicily and Malta were popular for its clothing merchandise. People flocked in from all over the world. Roman festivities included consumption of large portions of wine. And the production of wine in large scales not only served Rome but also enabled her to export it to other countries.

'Pizza' a delight of the Italian origin has become a global phenomenon today. Countries across the world have adapted it in to their own style of cuisines. But the word 'pizza' is strikingly relevant today. Likewise wine, fish and food oil were also popularly traded in ancient Rome.

The most powerful clan of Rome and the wealthier were settlers in the place of Capua. Which was also a place for training gladiators. Luxury goods were also a demand for many especially those belonging to the urban class. Glassware, Pottery and Ornament making also gained significant popularity in around Rome.

Moses Finley argues in his book The Ancient Economy (1973) that local traders in ancient Rome vibrantly dwelled themselves in trade and thereby it enabled them to invest in purchases of land from the profits they made from it. The economic activity also moved swiftly because citizens of Rome felt the need to improve their status in the society and thereby transformed the Mediterranean power to a global power.

\section{Key Findings}

- Ancient Rome's military power projection is reminiscent of Italy's current capacity to hold and build Aircraft Carriers that defines its Superpower status in its own merit.

- Military Strategies employed by Julius Ceaser and Quintus Fabius Maximus are famous world over and some of them related to spying have been employed during The First World War, The Second World War and The Cold War.

- Her projection of soft powers included in making world famous glassware and ornament making. And its power projection continues through brands like Armani and Ferrari.

- Famous writers like Quintus Ennius praised ancient Rome for its magnificence. And even to this day great writers like Dan Brown is fascinated by the architecture of Rome and attributes his ardent attention through his novels Angels and Demons (2000) and Inferno (2013).

- River Tiber was a source of consumption for the citizens of ancient Rome and served, as a symbol of strong existence at the global stage and likewise the city of Naples today is a famous tourist hub known for its beaches.

- Cities like Silcily and Malta were famous tourist hubs during the reigning times of ancient Rome. Venice and Rome today are without doubt one of the top tourist destinations for citizens all over the world.

- Some of the planets in our solar system like Mercury, Venus, Mars, Jupiter and Neptune are all named after ancient Roman Gods and Goddesses.

- Italy is one of the founding members of both North Atlantic Organization (NATO) and the European Union (EU) demonstrating its alliance and ability to be part of a strong working group. The ancient Rome helped Greece when she needed support to fight against the invading Macedonia thus demonstrating her fondness in helping her neighbors at the time of dire duress.

- The ancient Rome contained huge gold reserves and its taxation was monitored. And ltaly is one of the top ten strongest performing economies in the world today.

- The Roman wine was famous world over and the demand for it realized her to export them in abundance. And one of the most delicious cuisines today 'Pizza' stands tall in the annals of food variety world over also had its offshoots from Italy.

- The ancient Roman history is filled with true stories of both love and betrayal. And famous plays Antony and Cleopatra (1607) and Julius Ceaser (1599) by William Shakespeare made them popular one step further. 
- Many of the words in English today have its roots in Latin. 'Citizen' is one such word. The suffix 'zen' in Latin 'gens' refers to clan.

\section{Conclusion}

Globalization is the key word since the beginning of the $21^{\text {st }}$ century. Networking and Interconnectedness are the sub systems that add to its vibrancy and overall reach. About two thousand years ago the ancient city of Rome became a republic with similar attributes. The early Roman settlers were traders and lived in the coastlines. But later became one of the most advanced cities and thereby an evolution of a new and advanced civilization.

Global alliances such as the NATO, CENTO, SEATO and the Warsaw Pact were institutionalized immediately after the end of The Second World War in 1945. But except the NATO (North Atlantic Treaty Organization) all the rest have lost their prominence.

The United Nations became a global body on the October $24^{\text {th }} 1945$ and headquartered in New York, US. As of current global order about 190 countries are its members including the five permanent members of the Security Council: US, UK, Russia, France and China. But on parallel lines The European Union (EU) and The BRICS are also emerging as new alliance of nations competing for new global order.

Rome was one of the first cities in the ancient world to form such successful alliances. Its power was to integrate itself with its allies not with an expansionist mind set alone; it was able to provide an umbrella to protect smaller towns and cities from external threats and invasions.

Sociologist Max Webber famously argued that State is the single most legitimate autonomy to provide security to an individual. Rome underwent significant changes since the start of First BC. She turned to a western power rising from the Mediterranean and becoming a dominant player at a global stage.

Between $753 \mathrm{BC}$ and $476 \mathrm{AD}$ Rome established itself as one of the most powerful and advanced civilizations in the world. Rome's architecture, trade and economy reverberate not only in history but also in the current global order of governance as well. Likewise, Italy in the $21^{\text {st }}$ century is a powerhouse in the today's global world order extending its sphere of influence at all levels from policy making to execution.

\section{References}

Balot, Ryan K. (2006). Greek Political Thought. Blackwell Publishing Ltd. Oxford. ISBN - 13: 978-1-4051-0030-4. Print.

Baylis, John \& Smith, Steve \& Owens, Patricia. (2011). The Globalization of World Politics: An Introduction to International Relations. Oxford University Press Inc. New York. ISBN 978-0-19-956909-0. Print.

Brown, Dan. (2009). Angels and Demons. RHUK; Export ed Edition. ISBN - 10: 0552161268. Print.

Elliott, Jackie. (2013). Ennius and the Architecture of the Annales. Cambridge University Press. ASIN: B00GA22FZK.

Finley, Moses. I. (1973). The Ancient Economy. University of California Press. ISBN-10: 0520024362. Print.

Freeman, Charles. (1999). Egypt, Greece and Rome Civilizations of the Ancient Mediterranean. Oxford University Press Inc. New York. ISBN 0-19-872194-3. Print.

Keith, A.M. (2013). Propertius: Poet of Love and Leisure. Gerald \& Duckworth Co Limited. ISBN - 10: 0715634534. Print.

Livy. (2010). Livy's History of Rome: The First Five Books, Volume 47. Nabu Press. ISBN - 10: 1145727174. Print.

Pollio, Vitruvius \& Granger, Frank Stephen. (2011). Vitruvius, On Architecture. Nabu Press. ISBN - 10: 124568602X. Print.

Ritzer, George. (2000). The Blackwell Companion to Major Social Theorists. Wiley - Blackwell. ISBN - 10: 0631207104. Print. 